\title{
A Study on the Development and Effectiveness of a Teaching-Learning Model Based on Flipped Learning and PBL
}

\author{
Jungyoun $\mathrm{Ha}$
}

Assistant Professor, Department of Early Childhood Education, Suncheon Jeil College, Republic of Korea

\section{ABSTRACT}

Objectives: This study reports on the development and evaluation of a model for the application of the studentcentered teaching methods to develop core competencies suitable for future society.

Methods: Using mixed methods, this study is the most recently developed and the most widely used teaching practice at the site. Flipped learning and PBL, which can be designed as a systematic self-learned learning model can be used to identify and develop learning (capabilities and skills) in a classroom.

Results: The study found that first, differences in learning outcomes between flipped learning and PBL instructional models were identified within a control and experimental group, but the difference in self-directed learning (SDL) abilities was more significant in both the pre- and post-test. Second, the in-depth student interview data reported levels of interest in learning, participation in class, and satisfaction was higher than that of the previous class experience of theory of teaching.

Conclusions: First, based on the results of this study, the success or failure of the flipped learning and PBL model depends on how professors prepare and operate the classroom activities. Since the core of the flipped learning and PBL models is to increase learner participation, sufficient learner preparation and effort is necessary. Second, the flipped learning and PBL models require students to take a proactive approach to learning based on the knowledge and concepts explored outside the classroom. 


\section{INTRODUCTION}

The 4th industrial revolution is expected to bring a fundamental change to daily human life. Under these circumstances, critical thinking, creativity and problemsolving skills, communication and collaboration skills are seen as core competencies for students who will be the mainstay of future societal needs. Education is required above all to foster the core competencies that future society demands, Education tailored to the diverse characteristics and needs of learners is mandatory for higher education students to properly respond to and pave the way for themselves and others within society. Therefore revision of curricula centered on the introduction of learner-centered teaching methods is imperative. Changes geared toward offering a wide variety of learner-centered activities to nurture the future graduate can create new value in future society in response to the changing needs of the 21st century (Jin, et. al., 2016).

In order for college students to develop the core competencies necessary for future society, the kind of instruction that can stimulate them to take initiative, become divergent in their thinking and feel free to ask questions is required.

Lately, a lot of alternative teaching methods have been introduced in South Korea; these take center stage as learner-centered initiatives and have proven effective. Good examples are flipped learning and problem-based learning (PBL). Flipped learning draws lots of attention not only in elementary and secondary schools but from universities. It has rapidly spreads within our country's education sector. In flipped learning, short video clips of classes are provided so that students can see them in advance of class attendance, and then they can engage more actively in various tasks in class. The benefits of flipped learning are that makes it possible for students to prepare for their lessons in advance and enrich their more applied learning during class. In addition, more individualized learning can be provided for students.

PBL is a teaching strategy to that encourages acquisition of knowledge through problem-solving, that is having students find significant solutions on their own. They are given unstructured problematic scenarios about a particular phenomenon that occurs in the real world. This is a way that learning that takes place through a series of processes aimed at solving the given problem through both individual and cooperative learning (Jo, et. al., 2003; Barrows, 1992). What matters in PBL is the process of dealing with the stimulus for thinking about the problem, not just finding the solution itself. Students are able to take advantage of their own ways of accessing empirical knowledge to learn about the whole process of problem solving - to approach the problem openly, secure the necessary materials, compare opinions from different people, consider alternative, assert one's own tentative conclusion and be persuasive in their respective arguments.

The purpose of this study was to redesign flipped learning and PBL into a systematic model for teaching and learning, to develop student-participatory instructional activities and to examine the applicability and effectiveness of the activities in actual classrooms. Two research questions were posed:

1. What learning effects do instructions based on flipped learning and PBL have on self-directed learning capabilities, learning flow, problem-solving skills and self-efficacy?

2. What are the learning experiences of students who receive this alternative set of instructions? 


\section{METHOD}

\section{The Subjects and Procedures}

The subjects in this study were 40 early childhood education students who took a "curriculum" course, one of the courses for the teaching profession within a three-year college program in Jeollanam-do.

To develop a model for teaching and learning based on flipped learning and PBL, the ADDIE model, a systematized instructional design model that is in wide use for instructional design, was used. In the first stage of analysis, the learners' profiles were appraised. A survey was conducted on the preservice early childhood teachers who were the subjects in this study to find out their awareness of theoretical instructions for the teaching profession and their satisfaction level before and after taking classes in this study. In this design stage,, a model for teaching and learning combined flipped learning and PBL. Numerous teaching materials and evaluation tools were developed. At implementation, the model for teaching and learning and the teaching materials that were developed were utilized. In the stage of evaluation, any effects on self-directed learning (SDL) capabilities, learning flow, problem-solving skills and self-efficacy was measured. The manner in which the students responded to the new model and what effects the education produced were confirmed. The process of this study is shown in Figure1.

\begin{tabular}{|c|c|}
\hline Stage & What to Do \\
\hline $\begin{array}{c}\text { Design and } \\
\text { Operation }\end{array}$ & $\begin{array}{l}\text { - Design and develop a flipped learning- and PBL- } \\
\text { based model for teaching and learning on the basis } \\
\text { of the ADDIE model. } \\
\text {-Apply it to a theoretical course(curriculum) for the } \\
\text { teaching profession in the department of early } \\
\text { childhood education ( } 40 \text { students in two classes). }\end{array}$ \\
\hline $\begin{array}{c}\text { Analysis of } \\
\text { effects }\end{array}$ & $\begin{array}{l}\text {-Analyze the effects of the model. } \\
\text { - Explore the applicability of the model and give some } \\
\text { suggestions. }\end{array}$ \\
\hline
\end{tabular}

Figure 1. The process of the study

\section{Method and Instrumentation}

To design an instructional model, the awareness of the students about theoretical courses for the teaching profession and their needs were analyzed. Then the effects of the model, as outlined above were investigated before and after the application of the model. In addition, students were interviewed about their perceptions of the learning effects of the new model for teaching and learning. The interviews were recorded with their consent consistent with ethics approval, and then the recording materials were transcribed.

The inventories on SDL capabilities, learning flow, problem-solving skills and self-efficacy were used to test the effects of the model based on flipped learning and PBL. The instrument used to measure SDL capabilities was the test used in Woo's (2015) study. For learning flow, eight items of Park's (2010) Learning Flow Inventory were used - these were related to attention on learning tasks. Concerning problem-solving skills, eight items of Version B of PSI(Problem Solving Inventory) were used. These measured cognitive ability, that is one's own problemsolving behaviors or attitudes, confidence about one's own problem-solving skills. Finally, eight items of Park's (2010) inventory were utilized to assess self-efficacy. These items covered learning confidence and academic perseverance. The 40 students were divided into a control group of 22 and an experimental group of 18 , and both groups were tested twice, once each before and after the experiment. The reliability of the instruments used in this study is as follows: 
Table 1. The reliability of the instruments

\begin{tabular}{|c|c|c|c|c|c|}
\hline \multirow{2}{*}{\multicolumn{2}{|c|}{ Classification }} & \multirow{2}{*}{ Item No. } & \multicolumn{3}{|c|}{ Cronbach' } \\
\hline & & & Pretest & Posttest & Total \\
\hline \multirow{3}{*}{$\begin{array}{l}\text { Self-directed } \\
\text { learning } \\
\text { capabilities }\end{array}$} & $\begin{array}{c}\text { The control group } \\
\text { of } 22\end{array}$ & \multirow{3}{*}{8 items } & .790 & .548 & .668 \\
\hline & $\begin{array}{c}\text { The experimental } \\
\text { group of } 18\end{array}$ & & .668 & .653 & .825 \\
\hline & $\begin{array}{l}\text { The total group } \\
\text { of } 40\end{array}$ & & .759 & .710 & .865 \\
\hline \multirow{3}{*}{ Learning flow } & $\begin{array}{c}\text { The control group } \\
\text { of } 22\end{array}$ & \multirow{3}{*}{8 items } & .801 & .799 & .899 \\
\hline & $\begin{array}{c}\text { The experimental } \\
\text { group of } 18\end{array}$ & & .748 & .703 & .852 \\
\hline & $\begin{array}{l}\text { The total group } \\
\text { of } 40\end{array}$ & & .762 & .754 & .872 \\
\hline \multirow{3}{*}{$\begin{array}{l}\text { Problem-solving } \\
\text { skills }\end{array}$} & $\begin{array}{c}\text { The control group } \\
\text { of } 22\end{array}$ & \multirow{3}{*}{8 items } & .716 & .654 & .827 \\
\hline & $\begin{array}{c}\text { The experimental } \\
\text { group of } 18\end{array}$ & & .776 & .769 & .876 \\
\hline & $\begin{array}{l}\text { The total group } \\
\text { of } 40\end{array}$ & & .755 & .741 & .863 \\
\hline \multirow{3}{*}{ Self-efficacy } & $\begin{array}{c}\text { The control group } \\
\text { of } 22\end{array}$ & \multirow{3}{*}{8 items } & .758 & .812 & .888 \\
\hline & $\begin{array}{c}\text { The experimental } \\
\text { group of } 18\end{array}$ & & .726 & .786 & .881 \\
\hline & $\begin{array}{l}\text { The total group } \\
\text { of } 40\end{array}$ & & .759 & .823 & .896 \\
\hline \multirow{3}{*}{ Total } & $\begin{array}{c}\text { The control group } \\
\text { of } 22\end{array}$ & \multirow{3}{*}{32 items } & .914 & .895 & .950 \\
\hline & $\begin{array}{c}\text { The total group } \\
\text { of } 18\end{array}$ & & .882 & .874 & .935 \\
\hline & $\begin{array}{c}\text { The total group } \\
\text { of } 40\end{array}$ & & .903 & .904 & .949 \\
\hline
\end{tabular}

\section{Analysis}

First, Levene's homogeneity of variance test was utilized to check the equivalence of the control group and the experimental group to determine the effectiveness of the model based on flipped learning and PBL. Second, the pretest and posttest results of the two groups were analyzed to check how much improvements the model brought to learning outcomes. Paired-samples t-test was used for the pos-ttest results. Independent-samples t-test was utilized to analyze intergroup differences in average scores to see if there were any differences between the two groups after the application of the model. Third, four volunteer students were interviewed to confirm their learning experiences. The interviews were recorded with their consent, and the transcribed data were analyzed. Colaizzis (1978) data analysis method was used: Significant statements, sentences or phrases were coded as emergent themes. The data collected from the four inventories within the pretest and posttest were analyzed by SPSS 20 and the transcribed interview data were analyzed by NVivo 11 .

\section{THE DESIGN AND OPERATION OF THE MODEL FOR TEACHING AND LEARNING BASED ON FLIPPED LEARNING AND PBL}

\section{The Stage of Analysis}

The early childhood education students participated in an on-line survey. They were asked to give one or more answers to the question "What's most difficult or hard to learn or do in theoretical instructions for the teaching profession?", Theories and pedagogy terms were most widely pointed out: $n=31$ cases( $43.66 \%)$; the contents of instructions or textbooks $\mathrm{n}=15$ cases(21.13\%); task preparations, $\mathrm{n}=10$ cases $(14.08 \%)$ : ways of proceeding with instructions, $\mathrm{n}=7$ cases $(9.86 \%)$. This finding implies that students found theoretical courses for the teaching profession more difficult than practical major courses in early childhood education. In terms of learning readiness, the largest group that $n=23(57.5 \%)$ tended to take classes without reading textbooks. This suggests that they weren't basically ready to assume responsibility for classes. Around class participation, more than half $\mathrm{n}=22(55 \%)$ were inclined to be passive, and $n=13(32.5 \%)$ were more active. In general, the students participated in theoretical classwork in a passive way, indicating that change in teaching methods is required to boost class participation. 


\section{The Design Stage}

As instructional design is a vital process to determine whether the educational objectives are achieved or not, a systematic approach should be taken to make every factor of the whole instruction work in a mutually organic manner. As for the basic model for the combination of flipped learning and PBL-based models for teaching and learning, theoretical instructions that applied this model were conducted four times a week, two hours each, as part of the curriculum for the teaching profession in the second semester of the second year in 2017. The period from the third to the 10th week (eight weeks) was divided into four rounds of two weeks each (four hours). In each of the rounds, flipped learning was applied in the introductory stage, and PBL was applied in the development and wrapping-up stages.

In the pre-instructional stage, the teacher did research on the textbook to set up each session's objectives and formulate a teaching strategy. Flipped learning video clips, individual ping-pong quizzes, online team quizzes and team-based problem-solving tasks were prepared, and the prepared flipped learning video clips were uploaded onto an online cafe so that the students could take classes after seeing the video clips.

The instructional stage consisted of the following: (1) The teacher had the students answer the quizzes using their smartphones after starting a class. PPT was used for quizzes, and the teacher could immediately check answers on the smartphone. (2) The online team quizzes were posted on the Kakao talk chat room for the class so that every team member could join forces to solve the problems. A timer was put up on the screen to help the students solve problems within the time appointed. (3) A core lecture and an advanced lecture were given about the key points from the textbook. (4) Problem-solving tasks were assigned to each team in the final step of the first week, and the teams were given time to check the problems and solve them by dividing their roles. (5) In the first session of the second week of each round, each team engaged in problem solving. Every team member did cooperative learning by respectively serving as a chairperson, a recorder, a presenter and a person who did further research. The teacher assisted the teams while they solved the given tasks. After every team finished the tasks, they gave a presentation on how they solved the problems, and then had a Q\&A session. After all the teams gave a presentation, the teacher gave a comment on their presentations.

\section{The Development Stage}

A flipped learning video clip should be relatively short, about 15 minutes long. An application "Explain Everything" was used to shoot the flipped learning video clips. In the first session of each round, the individual ping-pong quizzes were presented. These quizzes made it possible to check whether the students prepared their lessons and whether they knew the basic essentials. The online team quizzes made it possible to do cooperative learning because every team member could solve them together. Google Docs was used to give the team quizzes through URL. The students were able to check the right answers immediately after submitting their answers, and to give additional explanations when their answers were wrong. The team-based problem-solving tasks, which were the core of the instructions, was a process to solve more advanced problems together by taking advantage of what they had learned. Every team member had to gather all sorts of materials, produce written results and present the results collaboratively. The teacher needed to put a lot of time and effort in developing the problem-solving tasks. 


\section{RESULTS}

\section{Homogeneity Test Results}

To confirm the learning effects of the teaching-learning model based on flipped learning and PBL, a homogeneity test was carried out to see whether the control group and the experimental group were equivalent or not. Levene's homogeneity of variance test was used, and the results are shown in Table 2. There were equal variances between the two groups in the pretest and posttest results of all the four variables that were self-directed learning capabilities, learning flow, problem-solving skills and self-efficacy.

Table 2. The results of Levene's homogeneity of variance test for the control group and the experimental group

\begin{tabular}{|c|c|c|c|}
\hline \multirow{2}{*}{\multicolumn{2}{|c|}{ Classification }} & \multicolumn{2}{|c|}{ Levene's Homogeneity of Variance Test } \\
\hline & & $F$ & $P$ \\
\hline \multirow{2}{*}{$\begin{array}{l}\text { Self-directed learning } \\
\text { capabilities }\end{array}$} & Pretest & .014 & .906 \\
\hline & Pretest & .313 & .579 \\
\hline \multirow{2}{*}{ Learning flow } & Pretest & .443 & .510 \\
\hline & Pretest & .560 & .459 \\
\hline \multirow{2}{*}{ Problem-solving skills } & Pretest & .131 & .720 \\
\hline & Pretest & 2.286 & .139 \\
\hline \multirow{2}{*}{ Self-efficacy } & Pretest & .002 & .967 \\
\hline & Posttest & 1.023 & .318 \\
\hline
\end{tabular}

\section{Learning Effects}

To determine whether the model based on flipped learning and PBL made any differences to learning effects, paired-samples t-test was conducted to find out how much improvements the control group and the experimental group showed in self-directed learning capabilities, learning flow, problem-solving skills and self-efficacy. The results are shown in Table 3.

Both of the control group and the experimental group showed statistically significant improvements in most of the four variables. The control group showed a significant rise of scores in every variable except self-efficacy $(t=1.93)$, and the experimental group showed a significant rise in scores in every learning effect variable that was self-directed learning capabilities, learning flow, problem- solving skills and self-efficacy. Moreover, the experimental group showed better improvements than the control group when the pretest and posttest results were both analyzed.

Table 3. The results of the paired-samples t-test on the pretest and posttest results of the control and experimental groups

\begin{tabular}{|c|c|c|c|c|c|c|c|}
\hline \multirow{2}{*}{\multicolumn{2}{|c|}{ Classification }} & \multicolumn{2}{|c|}{ Pretest(A) } & \multicolumn{2}{|c|}{ Posttest(B) } & \multirow{2}{*}{$\begin{array}{l}\text { The Level of } \\
\text { Improvement } \\
\text { (B-A) }\end{array}$} & \multirow{2}{*}{$t(p)$} \\
\hline & & $\mathbf{M}$ & SD & M & SD & & \\
\hline \multirow{4}{*}{$\begin{array}{c}\text { The control } \\
\text { group }\end{array}$} & $\begin{array}{l}\text { Self-directed } \\
\text { learning } \\
\text { capabilities }\end{array}$ & 3.32 & 0.45 & 3.55 & 0.33 & 0.23 & $4.84^{* * *}$ \\
\hline & $\begin{array}{l}\text { Learning } \\
\text { flow }\end{array}$ & 3.35 & 0.49 & 3.52 & 0.47 & 0.17 & $3.88^{* * *}$ \\
\hline & $\begin{array}{l}\text { Problem- } \\
\text { solving skills }\end{array}$ & 3.28 & 0.43 & 3.63 & 0.39 & 0.35 & $5.85^{* * *}$ \\
\hline & Self-efficacy & 3.29 & 0.42 & 3.39 & 0.47 & 0.10 & 1.93 \\
\hline \multirow{4}{*}{$\begin{array}{l}\text { The } \\
\text { experimental } \\
\text { group }\end{array}$} & $\begin{array}{c}\text { Self-directed } \\
\text { learning } \\
\text { capabilities }\end{array}$ & 3.69 & 0.50 & 4.02 & 0.43 & 0.33 & $5.74^{* * *}$ \\
\hline & $\begin{array}{l}\text { Learning } \\
\text { flow }\end{array}$ & 3.35 & 0.50 & 3.73 & 0.44 & 0.38 & $5.36^{* * *}$ \\
\hline & $\begin{array}{l}\text { Problem- } \\
\text { solving skills }\end{array}$ & 3.52 & 0.54 & 3.93 & 0.47 & 0.41 & $5.58^{* * *}$ \\
\hline & Self-efficacy & 3.58 & 0.45 & 3.74 & 0.46 & 0.16 & $4.25^{* * *}$ \\
\hline
\end{tabular}

$p^{*}<.05, p^{* *}<.01, p^{* * *}<.001$

\section{Intergroup Differences in the Learning Effects}

There were differences between the control and experimental groups in average scores in SDL capabilities, and there were significant intergroup differences both on the $\operatorname{pretest}\left(t=2.47^{\star}\right)$ and the posttest $\left(t=3.90^{* * *}\right)$. Concerning the level of the intergroup differences, the disparity on the post-test (a score of 0.47 ) was larger than that on the pre-test (a score of 0.37). In the case of learning flow, no statistically significant differences were found either on pretest or posttest, but the intergroup disparity on the posttest was greater. In problem-solving skills, there was no 
statistically significant intergroup difference on the pre-test $(\mathrm{t}=1.55)$, but a statistically significant intergroup difference was found on the post-test $\left(t=2.21^{\star}\right)$. In the case of selfefficacy, there were statistically significant differences both on the pretest $\left(\mathrm{t}=2.07^{\star}\right)$ and the post-test $\left(\mathrm{t}=2.37^{\star}\right)$. Also, the differences of scores between the control group and the experimental group were larger for the post-test.

Table 4. The results of the independent-samples t-test on the pretest and posttest scores

\begin{tabular}{|c|c|c|c|c|c|c|c|}
\hline \multirow{2}{*}{\multicolumn{2}{|c|}{ Classification }} & \multicolumn{2}{|c|}{ Pretest(A) } & \multicolumn{2}{|c|}{ Posttest(B) } & \multirow{2}{*}{$\begin{array}{l}\text { The Level of } \\
\text { Improvement } \\
\text { (B-A) }\end{array}$} & \multirow{2}{*}{$t(p)$} \\
\hline & & $M$ & SD & $M$ & SD & & \\
\hline \multirow{2}{*}{$\begin{array}{l}\text { Self-directed } \\
\text { learning } \\
\text { capabilities }\end{array}$} & Pretest & 3.32 & 0.45 & 3.69 & 0.50 & 0.37 & $2.47^{*}$ \\
\hline & Pretest & 3.55 & 0.33 & 4.02 & 0.43 & 0.47 & $3.90^{* * *}$ \\
\hline \multirow{2}{*}{ Learning flow } & Pretest & 3.35 & 0.49 & 3.35 & 0.50 & 0.01 & 0.05 \\
\hline & Pretest & 3.52 & 0.47 & 3.73 & 0.44 & 0.21 & 1.45 \\
\hline \multirow{2}{*}{$\begin{array}{l}\text { Problem- } \\
\text { solving skills }\end{array}$} & Pretest & 3.28 & 0.43 & 3.52 & 0.54 & 0.24 & 1.55 \\
\hline & Pretest & 3.63 & 0.39 & 3.93 & 0.47 & 0.30 & $2.21^{*}$ \\
\hline \multirow{2}{*}{ Self-efficacy } & Pretest & 3.29 & 0.42 & 3.58 & 0.45 & 0.29 & $2.07^{*}$ \\
\hline & Pretest & 3.39 & 0.47 & 3.74 & 0.46 & 0.35 & $2.37^{*}$ \\
\hline \multirow{2}{*}{ Total } & Pretest & 3.31 & 0.38 & 3.53 & 0.39 & 0.23 & 1.84 \\
\hline & Posttest & 3.52 & 0.34 & 3.85 & 0.35 & 0.33 & $3.04 * *$ \\
\hline
\end{tabular}

$p^{\star}<.05, p^{\star \star}<.01, p^{* \star \star}<.001$

\section{The results of the Interviews}

As a result of analyzing the transcribed interview data of the four students, the model based on flipped learning and PBL could be said to have produced the following learning effects:

\section{Learning Interest}

- I could understand well and got interested while listening to the flipped learning video clips.

- My understanding improved while repeatedly seeing the flipped learning video clips, reading the textbook and solving the quizzes and the problem-solving tasks, and it was interesting to do them.

"I became interested in the courses for the teaching profession thanks to the flipped learning videos and the instructions that used various methods. I found it interesting to solve the quizzes and perform the tasks with my team members, and the activities seemed to make the instructions for the teaching profession more accessible" (2-B-1).

"I took pleasure in the instructions during this semester. In the past, I just wrote what the professor explained, and it was interesting this time to talk to other students and give presentations in group" (2-D-1).

\section{Class Participation}

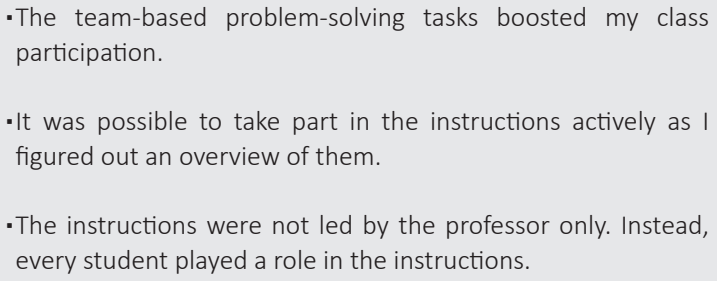

- The instructions were not led by the professor only. Instead, every student played a role in the instructions.

"I didn't feel any more that the team-based problem solving tasks were difficult to do because I took the classes after seeing the video clips. Rather, I was motivated to perform the tasks more actively. It seemed that I took the classes more actively as the team activities allowed me to feel free to talk to my friends in class" (2-B-2).

"I felt the way of teaching was fresh, and it gave an opportunity for me to listen more carefully. I think my class participation was boosted while our team members talked about each other's ideas and solved the problems together" $(2-\mathrm{C}-2)$

\section{Class Participation}

$$
\begin{aligned}
& \text { - They were the most satisfactory instructions. } \\
& \text { - The instructions helped me to learn on my own. } \\
& \text { - It was possible to broaden my horizon by actively attending } \\
& \text { every instruction. }
\end{aligned}
$$


"I used to forget everything I'd learned in other classes after taking tests, but these instructions were fruitful. I can still talk about what I had learned" (2-B-3).

"It was good to engage in activities in a liberal atmosphere. I was quite satisfied because I could participate in the instructions with my friends instead of merely listening" (2-D-3).

\section{Class Participation}

- The educational method was intriguing.

- Learner-centered education was conducted thanks to various teaching media.

"I'd never experienced this kind of instructions, and it was difficult to take these classes at first as I failed to fit in with them. But I found it interesting to keep taking the classes, and it was a good time to feel and learn a lot" (2C-4).

"It was good to use various teaching media. I could use the ping-pong app on the smartphone to arrange what I had prepared my lessons. And diverse instructional materials including the flipped learning video clips and reading materials that were posted on the online cafe all the time were helpful to my study" (2-B-4).

\section{DISCUSSION AND CONCLUSIONS}

This study was implemented to confirm what learning effects a teaching-learning model based on flipped learning and PBL produced after it was applied to a theoretical course for the teaching profession. First, an empirical analysis was carried out to determine whether there were any positive changes in the SDL capabilities, learning flow, problem-solving skills and self- efficacy of the students after the model was applied in class. Second, the students for whom the model was applied were interviewed to make a qualitative analysis of their learning experiences. The findings of the study were as follows:

First, the students were divided into a control group and an experimental group to see whether there were any differences in learning effects according to the use of the model based on flipped learning and PBL. As a result, there were significant intergroup differences in self-directed learning capabilities scores both on the pretest and posttest, and the experimental group made a better progress. In the case of learning flow and problem-solving skills, no statistically significant intergroup differences were found either on the pretest or on the posttest, but the experimental group showed a better improvement. In terms of selfefficacy, there were significant intergroup differences both on the pretest and the posttest, and the experimental group showed a better improvement. The experimental group showed more improvements in all the learning effect variables that were investigated in this study, which implies that the teaching-learning model based on flipped learning and PBL produced positive learning effects. The findings of the study lend credibility to the findings of earlier studies that instructions to which teaching-learning models based on flipped learning and PBL were applied had effects on the SDL capabilities, learning flow, problem-solving skills and self-efficacy of the students (Son, Ha, 2008; Woo, Kim, 2014; Joo, 2014; Cha, 2011; Csikszentmihalyi, 1996; Kasworm, 1983). All the findings of the study illustrated that the teaching-learning model based on flipped learning and PBL is a model of instruction to improve the SDL capabilities, learning flow, problem-solving skills and selfefficacy of students. It suggests that the model could exert a positive influence on the learning effects of preservice early childhood teachers.

Second, when the interview data of the students who took the classes were analyzed, they responded that their 
learning interest, class participation and class satisfaction became larger than in previous classes for the teaching profession. Moreover, they were more satisfied with the model for teaching and learning than with existing teachercentered teaching methods, and they also expressed a lot of satisfaction with the utilization of diverse instructional media. The findings of the study lend credibility to the findings of earlier studies that various learning experiences affected learning (Koo, Seo, 2014; Choi, 2007). In conclusion, it could be interpreted that the characteristics of the instructions, on which the teaching-learning model based on flipped learning and PBL was applied, enabled the students to study in a self-directed way and increased their class satisfaction and interest.

Given the findings of the study, there are some suggestions: First, the success or failure of the teachinglearning model based on flipped learning and PBL depends on how a professor prepares for classes and proceeds with them. As the key purpose of the model is to boost learner participation, comprehensive preparation and effort from a professor is required to bolster the effects of instruction. Second, a variety of learning activities in which students directly participate based on the knowledge and concepts they have acquired are conducted when this teachinglearning model based on flipped learning and PBL is in use. Therefore a professor should actively assist and guide students so that they could take the initiative in learning activities. Third, colleges should take various institutional measures to back up the learning activities of students through this model in an effective way. Administrative and financial assistance from colleges and CTL are of great importance for the entrenchment of this model as a successful model of instruction.

Although the teaching-learning model based on flipped learning and PBL, which was developed and applied in this study, proved to produce positive effects such as increasing the overall class satisfaction of the students, there is some room for improvement, and sustained efforts are necessary to do so. To be specific, more dynamic interactions should be stimulated in class, and plenty of feedback should be provided about the results of learning activities. The findings of the study might not be generalizable because a limited number of students were investigated given the conditions of the department. In future, what effects it produces should be tested after more students take classes in which this model is applied.

\section{REFERENCES}

Woo, K. A. (2015). A Study of Learning Effects of the PBL Using SNS. doctoral dissertation, Graduate School of Dongguk University, Seoul.

Woo, K. A., \& Kim, S. G. (2014). The Effect of SNS Use by Prospective Early Childhood Teachers in PBL-Based Class on the Flow and Problem-Solving Skills. Journal of Korean Child Care and Education, 10(6), 165-184.

Koo, Y. M., \& Seo, J. H. (2014). Effects of collaborative reflections using SNS on college student' learning motivation, problem solving competency and academic achievement in Creative Problem Solving activities. The Journal of Educational Methodology, 26(4), 659-685.

Park, H. G. (2010). Analysis of the Mediating Effect of the Learning Flow in the Relationship between Study Motivation Factors and Self-Directed Learning. doctoral dissertation, Graduate School Hong-Ik University, Seoul.

Shon, M., \& Ha, J. M. (2008). A Meta-Analysis on the Effects of Problem-Based Learning. The Journal of Educational Information and Media, 14(3), 225-251.

Jo, Y. S., Lee, H. J., B, E. J. \& Im, H. H. (2003). A Study on the Procedure of Problem Design for Problem-Based 
Learning. The Journal of Curriculum Studies, 21(3), 215-242.

Cha, S. B. (2011). An analysis of structural equation models(SEM) on university students' Social Network Service(SNS) participation and learning outcomes. doctoral dissertation, Graduate School of Konkuk University, Seoul.

Choi, J. I. (2007). A Case Study for the Application of PBL in Higher-Education : Focused on the Effectiveness of PBL Presented in Reflective Journal. Journal of Educational Technology, 23(2), 35-65.

Barrows, H. S.(1992). The tutorial process. Springfield, IL: Southern Illinois University School of Medicine.

Colaizzi, F. U.(1978). Psychological research as the phenomenogist views it, in R. S. Valle, and M. King (Eds), Existential-phenomenological Alternatives for Psychology, NY: Oxford University Press.

Csikszentmihalyi, M.(1996). Creativity: Flow and the psychology of discovery and invention. NY: Harper Collins.

Kasworm, C.E.(1983). An examination of self-directed learning contracts as an instructional strategy. Innovative Higher Education, 8(1), 45-54. 